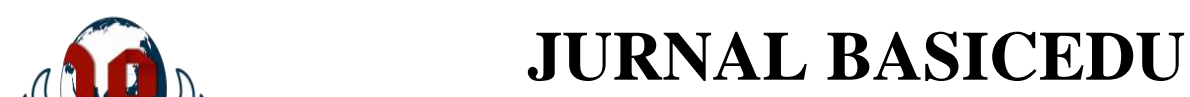

Volume 5 Nomor 3 Tahun 2021 Halaman 1175 - 1182

Research \& Learning in Elementary Education

https://jbasic.org/index.php/basicedu

PAHLAWAN

\title{
Analisis Attention Siswa Sekolah Dasar Dalam Pembelajaran Jarak Jauh di Masa Pandemi Covid-19
}

\author{
Nur Latifah ${ }^{1 凶}$, Asep Supena ${ }^{2}$ \\ Universitas Muhammadiyah Tangerang, Banten, Indonesia ${ }^{1}$ \\ Universitas Negri Jakarta, DKI Jakarta, Indonesia ${ }^{2}$ \\ E-mail: nurlatifah1v4@gmail.com ${ }^{1}, \underline{\text { supena2007@yahoo.com }}^{2}$
}

\begin{abstract}
Abstrak
Tujuan penelitin ini untuk menganalisis sejauh mana attention siswa dalam pembelajaran daring pada masa covid-19 di Sekolah Dasar Negeri Pegadungan 11 Pagi, Jakarta Barat. Subjek penelitian ini berjumlah enam puluh tiga yaitu tiga guru kelas dan 60 siswa. Peneliti dalam penelitian ini menggunakan pendekatan kualitatif dengan metode deskriptif bertujuan untuk menceritakan suatu data, peristiwa atau fenomena yang digali melalui wawancara mendalam dengan narasumber yang memiliki pengetahuan dan pemahaman serta pengalaman mendalam tentang fenomena tersebut. Metode deskriptif adalah metode yang menjelaskan atau mendeskripsikan suatu fakta, data, dan objek penelitian secara sistematis dan sesuai dengan situasi alamiah. Teknik pengumpulan data menggunakan wawancara, observasi, dan dokumentasi. Teknik analisis data ini mengunakan analisis kualitatif dengan mengunakan teori Miles dan Huberman meliputi reduksi data, penyajian data, dan penarikan kesimpulan. Hasil penelitian menunjukan bahwa Perencanaan Pembelajaran, Proses Pembelajran, dan Evaluasi Pembelajaran atapun hasil dari attention siswa di lihat berdasarkan atensi visual dan atensi auditori. Hasil Penelitian ini menunjukkan perencanaan pembelajaran di lakukan guru sebelum mengajar terkait perangkat pembelajaran, sedangkan dalam Proses Pembelajaran guru mengunakan media pembelajaran yang dapat menumbuhkan atensi siwa baik atensi auditori mau pun atensi visual, anensi visual siswa meningkat karna pengunan media pembelajaran yang menarik, dan pada aspek Evaluasi Pembelajaran guru mengunakan siswa unruk mengirimkan voice record sebagai penilaian.
\end{abstract}

Kata kunci: pembelajaran jarak jauh, atensi.

\begin{abstract}
The purpose of this research is to analyze the extent to which students' attention in online learning during the covid-19 pandemic at Pegadungan 11 Pagi Elementary School, West Jakarta. The subjects of this study were sixty-three people (three homeroom teachers and 60 students). Researchers in this study used a qualitative approach with descriptive methods to describe the data, events, or phenomena that were discovered through in-depth interviews with sources who have knowledge and understanding and in-depth experience of these phenomena. Descriptive method is a method that explains or describes a fact, data, and research object systematically and related to natural situations. Data collection techniques were done through interviews, observation, and documentation. This data analysis technique uses qualitative analysis using Miles and Huberman's theory including data reduction, data presentation, and drawing conclusions. The results showed that the Lesson Planning, Learning Process, and Learning Evaluation or the results of students' attention were viewed based on visual attention and auditory attention. The results of this study indicate that lesson planning is carried out by the teachers before teaching related to learning materials and media, while in the Learning Process the teachers used learning media that can foster students' attention both auditory attention and visual attention, students' visual attention increases because of the interesting arrangement of learning media, and in aspects of Learning Evaluation, teacher asked students to send voice records as an assessment.
\end{abstract}

Keywords: distance learning, attention.

Copyright (c) 2021 Nur Latifah, Asep Supena

Corresponding author:

Email : nurlatifah1v4@gmail.com

DOI $\quad$ : https://doi.org/10.31004/basicedu.v5i3.887

ISSN 2580-3735 (Media Cetak)

ISSN 2580-1147 (Media Onlin

Jurnal Basicedu Vol 5 No 3 Tahun 2021

p-ISSN 2580-3735 e-ISSN 2580-1147 


\section{PENDAHULUAN}

Seiring berjalannya waktu, pendidikan di Indonesia saat ini sedang menghadapi permasalahan terbesar yaitu adanya pandemi covid-19 yang mengakibatkan proses pembelajaran terbatas dari pembelajaran yang biasa di lakukan secara tatap muka harus berahli ke pembelajaran jarak secara langsung jauh (Azzahra, 2020). Tidak adanya proses pembelajaran tatap muka secara langsung di sekolah tentu akan menyulitkan guru untuk menyampaikan materi pembelajaran. Tidak hanya guru, siswa pun mengalami kesulitan yang sama dalam memahami materi. Ada banyak faktor yang mempengaruhi hal tersebut seperti kurangnya fasilitas yang dimiliki oleh siswa (Herliandry, Nurhasanah, Suban, \& Kuswanto, 2020) terutama pada siswa sekolah dasar dimana mereka sebelumnya masih banyak yang belum mempunyai alat komunikasi yang baik seperti smartphone (Syahrul \& Nurhafizah, 2021). Selain itu siswa masih banyak yang belum memahami betul bagaimana cara menggunakan internet untuk melakukan proses pembelajaran daring. Oleh karena itu, ini adalah tugas bersama yang harus segera diselesaikan, bukan hanya pemerintah namun sekolah dan guru harus memiliki inovasi sendiri agar terciptanya proses pembelajaran yang diharapkan meskipun dalam situasi seperti ini.

Perubahan terjadi karena adanya ketidaksesuaian yang mengakibatkan ketidakserasian di dalam pendidikan. Hal ini diakibatkan perkembangan virus yang menyebar dengan cepat di seluruh dunia terutama di indonesia yang berdampak pada pendidikan. Hal tersebut mempengaruhi perubahan-perubahan dalam kebijakan yang sudah diterapkan. Kebijakan baru yang terjadi pada dunia pendidikan yang mengubah pembelajaran yang biasanya dilakukan dengan tatap muka tetapi karena adanya pandemik akhirnya pembelajaran dilaksanakan melalui pembelajaran jarak jauh. Teknologi untuk saat ini dianggap sebagai pengganti posisi guru dalam pembelajaran (Al-Azawei \& Alowayr, 2020). Pembelajaran dengan menggunakan teknologi memudahkan guru untuk melakukan interaksi secara bersama-sama dengan siswa selama pembelajaran. Karena pembelajaran pada saat ini harus menekankan teknologi maka guru diharuskan untuk bisa menguasai teknologi agar pembelajaran dapat di variasi. Dalam pengembangan dan penerapannya, teknologi memiliki banyak aspek yang dapat diusulkan untuk mendukung pendidikan dalam peningkatan kualitas pendidikan nasional di Indonesia. Teknologi sangat penting dalam pendidikan, sehingga dapat menjadi fasilitator utama untuk meratakan pendidikan di Nusantara karena teknologi dapat dijadikan kemampuan belajar jarak jauh yang tidak lepas dari ruang, jarak dan waktu (Vagg, Balta, Bolger, \& Lone, 2020).

Attension adalah proses aktif membatasi informasi yang muncul berjuta-juta yang diterima dari sensorik, memori, dan proses kognitif lainnya sehingga hanya berfokus kepada suatu informasi yang dianggap penting, sementara informasi pengganggu lain yang dianggap kurang penting diabaikan (Sataloff, Johns, \& Kost, 2015). Attension dalam bahasa indonesia di sebut dengan Atensi yaitu merupakan proses kognitif untuk memilih suatu objek dan mempertahankan untuk tetap fokus memperhatikan objek yang dianggap penting serta mengambil keputusan dalam menyelesaikan masalah yang terdapat dalam prosesnya mempunyai peran penting dalam kegiatan belajar. Sedangkan Henry mengatakan bahwa Attention is the taking possession by the mind, in clear and vivid form, of one out of what seem several simultaneously possible objects or trains of thought. Focalization, concentration, and consciousness are of its essence (Wagner \& N, 2009) artinnya perhatian adalah kepemilikan oleh pikiran, dalam bentuk yang jelas dan jelas, salah satu dari apa yang tampak sebagai beberapa objek atau alur pemikiran yang mungkin secara bersamaan. Fokalisasi, konsentrasi, dan kesadaran adalah esensinya. Hasil dari terbatasnya kapasitas sistem informasi.

Fokus atensi terjadi pada seluruh pengalaman sensori yaitu Atensi visual dan Atensi Auditori (FischerBaum \& Campana, 2017). Hal ini yang akan menjasi analilisi terkait penentuan tingkat atenai siswa dalam pembelajaran jarak jauh. Karena perhatian bukan merupakan karakter bawaan dasar yang bersifat konstan dan stagnan, tapi perhatian berjalan secara aktif dan dinamis, untuk itu perhatian harus selalu dipupuk dan diperhatikan agar dalam kegiatan belajar mengajar berjalan secara aktif dan dinamis (Innocenti et al., 2019). Perhatian merupakan konsentrasi atau aktivitas jiwa seseorang terhadap pengamatan, pengertian. Seorang Pengajar harus bisa menarik perhatian siswa dalam kegiatan belajar mengajar, karena dengan adanya perhatian 
1177 Analisis Attention Siswa Sekolah Dasar Dalam Pembelajaran Jarak Jauh di Masa Pandemi Covid-19 Nur Latifah, Asep Supena

DOI : https://doi.org/10.31004/basicedu.v5i3.887

yang dimiliki oleh siswa maka akan timbul keinginan yang tertuju pada suatu hal tertentu. Dalam (Setiono \& Sari, 2016) perhatian diartikan sebagai hal memperhatikan; apa yang diperhatikan. Perhatian adalah minat atau apa yang disukai dan perhatian merupakan kepedulian atau kesiapan untuk memperhatikan (Sataloff, Johns, \& Kost, n.d.). Berdasarkan referensi tersebut maka disimpulkan bahwa Attention dalam bahasa indonesia berarti atensi yaitu salah satu hal yang dapat dilakukan oleh seseorang terhadap orang lain agar orang tersebut selalu merasa dirinya dianggap dan selalu dihargai. Oleh karena itu, perhatian mempunyai peranan yang sangat penting dalam proses kegiatan pembelajaran.

Berdasarkan dengan keadaan yang ada pada situasi pandemi covid-19 dari pengertian Attention yang sama dengan minat serta peran orang tua maka peneliti menganalisis sejauh mana Attention terhadap pembelajarn Jarak jauh di masa pandemi covid-19 ini berlangsung. Adapun hal yang menjadi tolak ukur analisis adalah Pembelajaran jarak jauh di lihat berdasarkan Perencanaan Pembelajaran, Proses Pembelajaran, dan Evaluasi Pembelajaran yang dilakukan analisis melalui guru dan siswa. Selain itu indekator dari Attention di bagi dalam dua hal yaitu Atensi visual dan Atensi Auditori.

\section{METODE PENELITIAN}

Penelitian ini mengunakan metode pendekatan kualitatif dengan metode deskriptif, metode deskriptif adalah metode yang menjelaskan atau mendeskripsikan suatu fakta, data, dan objek penelitian secara sistematis dan sesuai dengan situasi alamiah. Terkait hal yang diteliti, hasil penelitian lebih menekankan pada makna dari pada hasil, dan hasil penelitian tidak mengikat serta dapat berubah sesuai dengan kondisi yang dihadapi di lapangan penelitian dan diinterprestasikan dan dituliskan dalam bentuk kata-kata atau deskriptif berdasarkan fakta di lapangan (Sugiono, 2016). Tujuannya penelitianini adalah untuk memperoleh gambaran yang lengkap dan terperinci mengenai Attention. Penelitiandilaksanakan di Sekolah Dasar Negeri Pegadungan 11 Pagi, Jakarta Barat. Penelitian ini dilakukan secara intensif dalam waktu tiga minggu. Subjek penelitian adalah guru kelas dan siswa.

Teknik analisis data yang digunakan dalam penelitian ini adalah menggunakan model Milles dan Huberman, yaitu analisis dalam penelitian dilakukan secara interaktif. Adapun analisis data. tesebut sebagai berikut

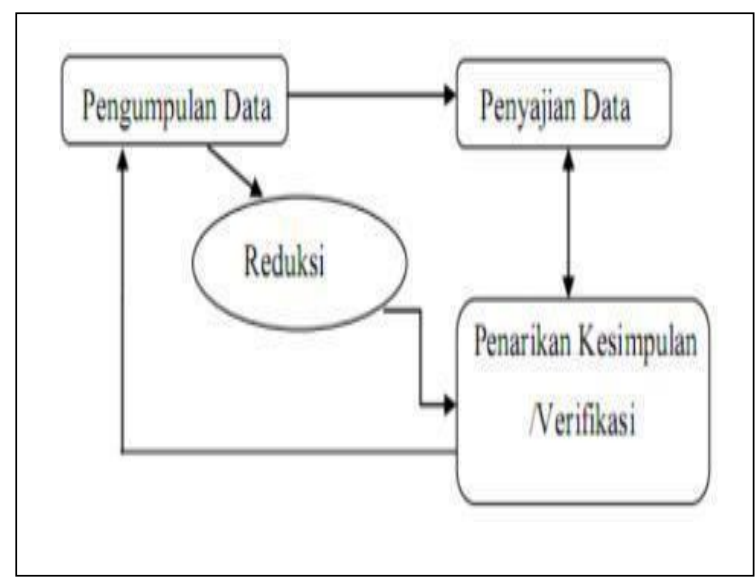

Gambar 1. Analisis Data Interatif ModelHubberman dan Miles

Tahapan penelitian ini dilakukan melalui tiga tahap yaitu tahap reduksi data (reduction) dilakukan untuk menentukan data yang relevan, bermakna, dan hal-hal penting berdasarkan penelitian yang dilakukan serta mendapatkan data yang peneliti butuhkan. Penyajian data (data display) yang diperoleh dalam penelitian ini disajikan dalam bentuk uraian singkat yang bersifat naratif (dengan teks). Penarikan kesimpulan (verification) 
1178 Analisis Attention Siswa Sekolah Dasar Dalam Pembelajaran Jarak Jauh di Masa Pandemi Covid-19 Nur Latifah, Asep Supena

DOI : https://doi.org/10.31004/basicedu.v5i3.887

peneliti akan menarik atau membuat kesimpulan dengan memberikan penjelasan dari kegiatan pengambilan data melalui observasi, wawancara, dan didukung oleh dokumentasi (Miles, Huberman, \& Saldana, 2014) Data diperoleh melalui berbagai sumber yaitu, wawancara semi terstruktur, observasi non-partisipan, dan dokumen kemudian data dikategorikan lalu di interprepsesikan. Triangulasi dilakukan untuk memeriksa dan mengecek keabsahan data.

\section{HASIL DAN PEMBAHASAN}

Hasil Penelitian ini di dasari oleh tiga rumusan masalah taitu Analisis Attention siswa Sekolah Dasar dalam Pembelajaran jarak jauh di masa Pendemis Covid 19 penelitian ini dilakukan melalui waawancara oleh narasumber menunjukkan tiga hal penting yang harus dipersiapkan dalam pembelajaran jarak jau yaitu: Perencanaan Pembelajaran, Proses pembelajaran, dan Evaluasi Pembelajaran yang dilakukan analisis melalui guru dan siswa. Dan terkait Attention peneliti melihat dari Atensi visual dan Atensi Auditori.

\section{Perencanaan Pembelajaran}

Perencanaan yang dilakukan guru Sekolah Dasar Negeri Pegadungan 11 Pagi Jakarta Barat dalam menghadapi pembelajaran berbasis daring pada masa covid19 ini yaitu guru membuat group whatsapp sebagai wadah penyampaian informasi dan kegiatan pembelajaran, guru memastikan semua siswa berperan aktif dan ikut serta dalam pembelajaran daring dengan memberikan link absen sebelum kegiatan pembelajaran di mula (Sitasari, 2019), guru memberikan pembelajaran dengan menggunakan aplikasi yang menarik bagi siswa agar pembelajaran tidak membosankan bagi siswa, dalam pembelajaran daring ini guru selalu merespon setiap pekerjaan siswa agar siswa termotivasi agar lebih baik lagi dalam mengerjakan tugas, hal yang terpenting yaitu kerjasama yang baik dengan orang tua siswa agar membimbing dan memperhatikan siswa pada saat proses pembelajaran daring berlangsung.

Kemampuan guru dalam pengembangan silabus pada masa covid-19 ini salah satunya kompetensi yang mewajibkan guru dapat menguasai teknologi pada era industri 4.0 adalah kompetensi Infornasi Teknologi (IT) (Asih, 2016), dengan kompentensi IT guru akan mampu mengembangkan silabus yang sesuai dengan masa pandemi covid-19 ini. Pada masa covid-19 ini guru wajib menyusun Rencana Pelaksanaan Pembelajaran (RPP) karena RPP merupakan rangkaian kegiatan yang akan disampaikan setiap harinya, tanpa adanya RPP rangkaian kegiatan tidak akan berjalan dengan sempurna. RPP yang digunakan pada saat ini disesuaikan dengan masa pandemi covid-19.

Tujuan penyusunan RPP pada masa Covid-19 ini agar pembelajaran dapat tercapai dengan maksimal serta materi dapat tersampaikan dengan baik ke siswa melalui daring dan tujuan kurikulum dapat tercapai. Perencanaan pembelajaran yang ideal pada masa pandemi ini yaitu harus di susun secara daring dan luring atau perpaduan antara keduanya, pembelajaran juga harus disesuaikan dengan kondisi sosial ekonomi peserta didik agar tidak terjadi kesenjangan pada aspek fasibilitas akses pembelajaran. Pembelajaran yang ideal juga tidak terlalu menyulitkan peserta didik pada pembelajaran saat ini peserta didik ditekankan pada keterampilan untuk kemandiriannya, maka harus disesuaikan dengan keadaan dan materi pembelajaran yang sudah direncanakan di RPP. Perencanaan pembelajaran yang ideal juga harus mengacu pada kurikulum darurat pada masa covid-19.

\section{Proses Pembelajaran}

Metode yang diterapkan guru Sekolah Dasar Negeri Pegadungan 11 Pagi Jakarta Barat dalam pembelajaran daring pada masa covid-19 salah satunya metode Blended Learning. Metode Blanded Learning (Tout, Kara, Talhi, \& Mourad, 2019) adalah sebuah kemudahan pembelajaran yang menggabungkan berbagai cara penyampaian, model pembelajaran, dan gaya pembelajaran. Blended learning juga sebagai sebuah kombinasi pengajaran langsung (face-to-face) dan pengajaran online, tapi lebih dari pada itu sebagai elemen dari interaksi sosial. Pada pembelajaran berbasis daring pada masa covid-19 guru menggunakan media untuk 
1179 Analisis Attention Siswa Sekolah Dasar Dalam Pembelajaran Jarak Jauh di Masa Pandemi Covid-19 Nur Latifah, Asep Supena

DOI : https://doi.org/10.31004/basicedu.v5i3.887

menjadikannya pusat perhatian siswa, medianya bisa berupa video youtube yaitu guru mencari materi yang sesuai di youtube lalu link youtube tersebut di share di group whatsapp, bisa juga menggunakan quizziz yaitu pembelajaran yang memudahkan guru untuk mengetahui kemampuan siswa dalam mengerjakan soal.

Media classcroom dapat memungkinkan guru dalam menyampaikan materi karena media classroom merupakan wadah pengumpulan tugas maupun kegiatan yang akan dilakukan siswa pada saat pembelajaran. Strategi yang guru lakukan dalam penyampaian materi berbasis daring pada masa covid-19 ini yaitu menggunakan strategi kontextual teaching dan learning yaitu strategi korelasi pembelajaran dengan kondisi aktual. Dalam pembelajaran daring materi yang guru sampaikan yaitu materi yang sesuai dengan KI, KD dalam silabus tentunya juga dengan menyesuaikan kondisi saat ini dan lebih mengutamakan life skill siswa dalam kehidupan sehari-hari.

Bentuk perhatian yang dilakukan guru melalui group whatsapp pada masa covid-19 yaitu dengan pemberian stimulasi berupa reward serta memberikan kesempatan untuk berperan aktif dalam setiap kegiatan pembelajaran. Pada pembelajaran berbasis daring ini ada beberapa Tahapan-tahapan yang guru lakukan yaitu: 1) Apersepsi melalui media online, 2) cek kehadiran dengan link Google Form, 3) melakukan kegiatan pendahuluan, 4) melakukan kegiatan inti, 5) Refleksi dan Penutup, dan 6).

\section{Evaluasi Pembelajaran}

Evaluasi pembelajaran pada siswa SD Negeri Pegadungan 11 Pagi Jakarta Barat dilakukan dengan menggunakan beberapa cara diantaranya: 1) penilaian tes formatif memanfaatkan aplikasi online seperti google form dan quizziz, 2) penilaian portofolio. Evaluasi yang guru berikan untuk siswa selama masa civid-19 yaitu dengan mengadakan ulangan harian melalui google form serta video untuk evaluasi keterampilan siswa. Cara penilaian portofolio yang guru lakukan selama masa covid-19 yaitu bisa dalam bentuk video yang dikirim melalui group whatsapp (Sung, Chang, \& Liu, 2016)

Mengukur dengan test, ulangan lisan melalui video call, maupun lewat pertanyaan ketika google meet guru dapat mengetahui apakah siswa sudah paham atau belum pada materi hari ini, guru juga dapat memberikan umpan balik pertanyaan secara lisan. Hambatan yang guru alami ketika melaksanakan evaluasi pembelajaran daring yaitu sarana yang dimana setiap anak ada yang memiliki hp sendiri dan ada juga anak yang harus menunggu hp pada saat hp tersebut dibawa ibunya pergi bekerja, hambatan yang lain yaitu sinyal yang dimana ada beberapa siswa yang ganggung terhadap sinyal jadi meyulitkan siswa untuk melakukan evaluasi bersama guru. Cara guru dalam menghadapi hambatan tersebut yaitu dengan cara memberikan keluangan waktu bagi siswa yang tertinggal dalam ulangan ataupun dalam evaluasi pembelajaran.

Hal-hal penting yang harus diperhatikan pada evaluasi pembelajaran berbasis daring pada masa covid ini yaitu memberikan waktu yang fleksibel dalam pengumpulan tugas, memberikan tugas yang tidak menyulitkan peserta didik, dan memberikan tugas yang tidak memakan kuota yang terlalu banyak (Latifah \& Supena, 2020. Tindakan yang guru lakukan jika terdapat siswa yang mendapatkan hasil evaluasi yang tidak tercapai pada pembelajaran daring ini yaitu dengan melakukan evaluasi dengan penugasan yang sifatnya tidak memberatkan sosial ekonomi siswa serta memotivasi siswa agar terus berusaha untuk mendapatkan nilai yang baik. (Latifah \& Supena, 2020).

\section{Atensi Visual}

Berdasarkan hasil angket terkait atensi visual siswa terhadap bahan ajar yang guru buat menunjukkan diagram sebagai berikut: 
1180 Analisis Attention Siswa Sekolah Dasar Dalam Pembelajaran Jarak Jauh di Masa Pandemi Covid-19 Nur Latifah, Asep Supena

DOI : https://doi.org/10.31004/basicedu.v5i3.887

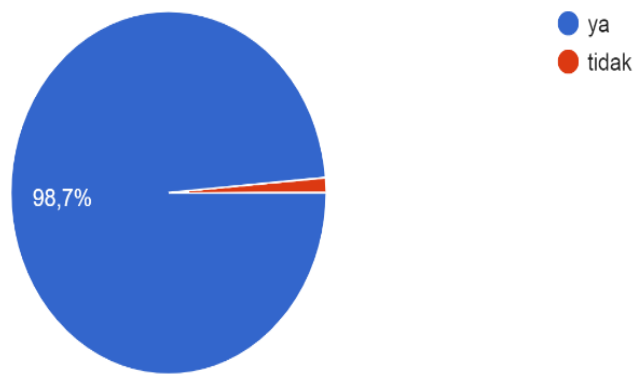

Gambar 1. Presentase tingkat Attensi Siswa dalam penggunaan media pembelajarna di lihat dari aspek visual

Terdapat 98,7\% skor dari pada kelas IV, V, dan VI menyatakan bahwa pembelajaran jarak jauh pada masa covid-19 membuat siswa senang terkait pada aspek visual karna guru menampilkan media pembelajarna menarik berupa video animasi (Zydney \& Warner, 2016), dan pengunaan media games sehingga siswa hasil dari angket terkait atensi visual memperuleh nilai tinggi, sehingga pembelajaran dapat menyenangan bagi siswa dan mempermudah siswa dalam memahami materi.

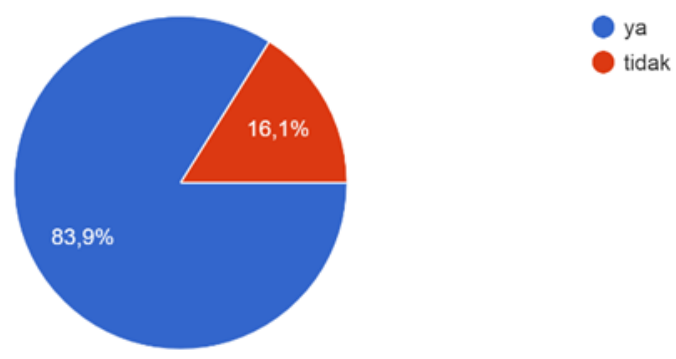

Gambar 2 : Intensitas Pengunaan Media terkait Atensi Visual

Dagram di atas menunjukkan $85,9 \%$ pada kelas IV, V, VI yang menyatakan bahwa penggunaan media (Zin, Sakat, Ahmad, \& Bhari, 2013) dilakukan setiap hari, terdapat 16,1\% siswa yang menyatakan bahwa penggunaan media dalam pembelajaran daring tidak di laksanakan setiap hari.

\section{Atensi Auditori}

Berdasarkan hasil angket terkait atensi Auditori siswa terhadap t bahan ajar yang guru buat menunjukkan diagram sebagai berikut

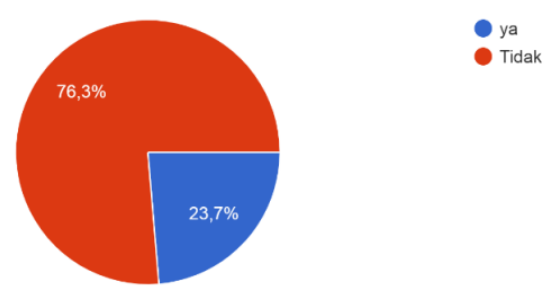

Gambar 3. Persentasi kendala dalam kegiatan pembelajaran terkait Atensi Auditori. 
1181 Analisis Attention Siswa Sekolah Dasar Dalam Pembelajaran Jarak Jauh di Masa Pandemi Covid-19 Nur Latifah, Asep Supena

DOI : https://doi.org/10.31004/basicedu.v5i3.887

Diagram ini menunjukkan 76,3\% pada kelas IV, V, dan VI mengelami kesulitan interaksi (Kim \& Jin, 2015) seperti suara yang tidak konsisten atau sering terputus-putus di karkan sinyal hal ini menjadikan kendala bagi siswa ketika guru menjelaskan mareti, sehingga siswa seringkali menanyakan ulang terkait materi yang sudah di jelskan.

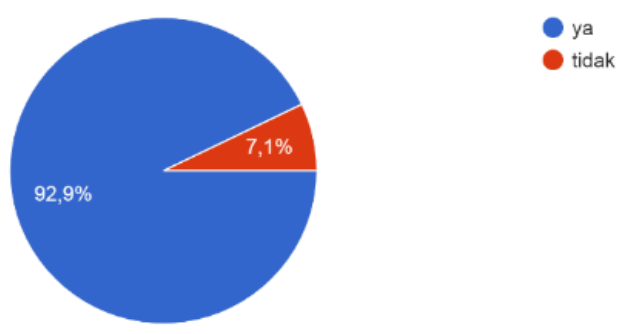

Gambar 3. Persentasi Penugasan guru terkait Atensi Auditori

Berdasarkan diagram di atas terdapat $92,9 \%$ pada kelas IV, V, dan VI menyatakan bahwa Guru memberikan penugasan (Nurjasmi \& Sudarsono, 2013) seperti mengirimkan voice terkait kesimpulan materi yang di ajarkan perubahan penugasan yang meminta siswa untuk mengirimkan voice record sebagai tanda bahwa siswa tersebut mamiliki atensi auditori.

\section{KESIMPULAN}

Dapat disimpulkan berdasarkan hasil wawancara guru kelas terkait pembelajaran jarak jauh di lihat berdasarkan perencanaan pembelajaran menunjukkan bahwa perencanaan pembelajaran di lakukan guru sebelum mengajar terkait perangkat pembelajaran, sedangkan dalam proses pembelajaran guru mengunakan media pembelajaran yang dapat menumbuhkan atensi siswa bait atensi auditori maupun atensi visual, hasil angket menunjukan atensi visual siswa meningkat karena pengguaan media pembelajaran yang menarik, dan pada aspek Evaluasi Pembelajaran guru juga mengunakan atensi auditori kepada siswa seperti menugaskan siswa unruk mengirimkan voice record sebagai penilaian hasil kerja.

Paham akan berbagai kendala yang terjadi dalam pembelajaran jarak jauh di masa pandemi covid penulis berharapkan penelitian ini dapat mendorong guru dan praktisi pendidikan untuk dapat lebih memperhatikan proses pembelajaran di lihat dari aspek atensi siswa, serta dapat meningkatkan khasanah refrensi terkait penelitian di bidang atensi pembelajaran.

\section{DAFTRA PUSTAKA}

Al-Azawei, A., \& Alowayr, A. (2020). Predicting the intention to use and hedonic motivation for mobile learning: A comparative study in two Middle Eastern countries. Technology in Society, 62, 101325. https://doi.org/10.1016/j.techsoc.2020.101325

Asih. (2016). Strategi Pembelajaran Bahasa Indonesia (1st ed.). Bandung: CV Pustaka Setia.

Azzahra, N. F. (2020). Mengkaji Hambatan Pembelajaran Jarak Jauh Indonesia di Masa Krisis Pandemi Covid19. Ringkasan Kebijakan, 19(2), 1-9.

Fischer-Baum, S., \& Campana, G. (2017). Neuroplasticity and the logic of cognitive neuropsychology. Cognitive Neuropsychology, 34(7-8), 403-411. https://doi.org/10.1080/02643294.2017.1389707 
1182 Analisis Attention Siswa Sekolah Dasar Dalam Pembelajaran Jarak Jauh di Masa Pandemi Covid-19Nur Latifah, Asep Supena

DOI : https://doi.org/10.31004/basicedu.v5i3.887

Herliandry, L. D., Nurhasanah, N., Suban, M. E., \& Kuswanto, H. (2020). Pembelajaran Pada Masa Pandemi Covid-19. JTP - Jurnal Teknologi Pendidikan, 22(1), 65-70. https://doi.org/10.21009/jtp.v22i1.15286

Innocenti, E. D., Geronazzo, M., Vescovi, D., Nordahl, R., Serafin, S., Ludovico, L. A., \& Avanzini, F. (2019). Mobile virtual reality for musical genre learning in primary education. Computers and Education, 139, 102-117. https://doi.org/10.1016/j.compedu.2019.04.010

Kim, T. H., \& Jin, S. H. (2015). Development of auditory design guidelines for improving learning on mobile phones. Computers and Education, 91, 60-72. https://doi.org/10.1016/j.compedu.2015.09.011

Latifah, N., \& Supena, A. (2020). Pelaksanaan Pembelajaran Anak Tunalaras di Masa Pendemi COVID-19 di Sekoalh Dasar. Jurnal Basicedu, 3(2), 801-812.

Miles, matthew B., Huberman, A. M., \& Saldana, J. (2014). Qualitative data Analysis "a methods sourcebook." United States of Amerika: SAGE Publications.

Nurjasmi, E., \& Sudarsono, A. (2013). Pengaruh pemberian stimulasi sensomotor terhadap tingkat arousal dan atensi anak normal usia 6-8 tahun di sdn pasir putih $01 \mathrm{kec}$. Sawangan depok. Jurnal Ilmu \& Teknologi Ilmu Kesehatan, 1(1), 68-72.

Sataloff, R. T., Johns, M. M., \& Kost, K. M. (n.d.). Meningkatkan Perhatian Siswa Kelas V SDN 2 Salakan Pada Mata Pelajaran PKn MElalui Metode Diskusi. Jurnal Kreatif Tadaluko Online, 2.

Sataloff, R. T., Johns, M. M., \& Kost, K. M. (2015). Fundamentals of HUMAN NEUROPSYCHOLOGY (Seven). New York, New York, USA: Worth.

Setiono, P., \& Sari, E. P. (2016). Penggunaan Media Pembelajaran Berbasis Visual untuk Meningkatkan Perhatian Siswa Pada Mata Pelajaran IPS Siswa Sekolah Dasar. Jurnal Gentala Pendidikan Dasar, 1(2), 215-238. https://doi.org/10.22437/gentala.v1i2.7114

Sugiono. (2016). METODE PENELITIAN (Kuantitatif, Kualitatif, dan R\&D (1st ed.). Bandung: Alfabeta CV.

Sung, Y. T., Chang, K. E., \& Liu, T. C. (2016). The effects of integrating mobile devices with teaching and learning on students' learning performance: A meta-analysis and research synthesis. Computers and Education, 94, 252-275. https://doi.org/10.1016/j.compedu.2015.11.008

Syahrul, S., \& Nurhafizah, N. (2021). Analisis Pengaruh Pola asuh Orang Tua Terhadap Perkembangan Sosial dan Emosional Anak Usia Dini Dimasa Pemdemic Corona Virus 19. 5(2), 683-696.

Tout, H., Kara, N., Talhi, C., \& Mourad, A. (2019). Proactive machine learning-based solution for advanced manageability of multi-persona mobile computing. Computers and Electrical Engineering, 80, 106497. https://doi.org/10.1016/j.compeleceng.2019.106497

Vagg, T., Balta, J. Y., Bolger, A., \& Lone, M. (2020). Multimedia in Education: What do the Students Think? Health Professions Education, 6(3), 325-333. https://doi.org/10.1016/j.hpe.2020.04.011

Wagner, \& N, H. (2009). Braint Imaging The Chemistry of Mental Activity. In Journal of Chemical Information and Modeling (Vol. 53). London, New York: Springer International Publishing.

Zin, M. Z. M., Sakat, A. A., Ahmad, N. A., \& Bhari, A. (2013). Relationship Between the Multimedia Technology and Education in Improving Learning Quality. Procedia - Social and Behavioral Sciences, 90(InCULT 2012), 351-355. https://doi.org/10.1016/j.sbspro.2013.07.102

Zydney, J. M., \& Warner, Z. (2016). Mobile apps for science learning: Review of research. Computers and Education, 94, 1-17. https://doi.org/10.1016/j.compedu.2015.11.001 